\title{
A comparison of metallic contents in lichen Pyxine subcinerea, its substratum and soil
}

\author{
V. Shukla $\cdot$ D. K. Patel $\cdot$ D. K. Upreti • \\ M. Yunus $\cdot$ S. Prasad
}

Received: 29 November 2011/Revised: 13 March 2012/Accepted: 22 April 2012/Published online: 12 May 2012

(c) CEERS, IAU 2012

\begin{abstract}
Chromium, copper, cadmium, lead, nickel, iron and zinc contents of a lichen species (Pyxine subcinerea Stirton) and mango bark collected from 12 sites in Haridwar city (Uttarakhand) were compared with soil, sampled from beneath the tree from which lichens were collected. The metal contents in lichen, bark and soil ranged from 1,573 to $18,793,256$ to 590 and 684 to $801 \mu \mathrm{g} \mathrm{g}^{-1}$, respectively. This clearly indicates that lichens accumulated higher amounts of metal compared to bark or soil. Statistical analysis revealed that metal concentration in lichens did not show significant linear correlation with the bark or soil. Pearsons correlation coefficients revealed negative correlation of $\mathrm{Pb}(r=-0.2245)$ and $\mathrm{Ni}(r=$ -0.0480 ) content between lichen and soil, which indicate direct atmospheric input of metals from ambient environment. Quantification and comparison of elemental concentration in lichens, its substratum and soil can provide valuable information about air quality in the collection area.
\end{abstract}

Keywords Atmospheric input - Bioaccumulation · Elemental content $\cdot$ Lichen $\cdot$ Statistical analysis

\footnotetext{
V. Shukla $(\square) \cdot$ M. Yunus

Department of Environmental Science,

Babasaheb Bhimrao Ambedkar (Central) University,

Raebareli Road, Lucknow 226025, India

e-mail: vertika_shukla@rediffmail.com

D. K. Patel · S. Prasad

Analytical Chemistry Division, Indian Institute of Toxicology

Research (CSIR-IITR), Mahatma Gandhi Marg,

Lucknow 226001, India

D. K. Upreti

Lichenology Laboratory, National Botanical Research Institute (CSIR-NBRI), Rana Pratap Marg, Lucknow 226001, India
}

\section{Introduction}

Lichens are slow-growing organism and form symbiotic associations between fungi, especially Ascomycota (mycobionts) and photoautotropic organisms (photobionts), mainly green algae (Trebouxiophyceae and Ulvophyceae) and/or cyanobacteria. Lichens occur in nearly all terrestrial ecosystems, such as tropical, temperate, boreal climatic regions and frequently dominate the landscape in extreme environments, such as Arctic, Antarctic and Alpine climatic regions (Green et al. 2011). Lichens are commonly used to assess environmental disorder, help to biomonitor air quality, forest age and health, and climate change (Bjerke 2011; Crespo et al. 2004; McCune 2000; Nimis et al. 2002).

Lichens present thalloid structure and they lack roots or waxy cuticles and mainly rely on the atmospheric input of mineral nutrients (Wolterbeek et al. 2003; Paoli and Loppi 2008). Lichens take up nutrients from (a) from the substratum on which it is attached (bark, as in the case of epiphytic lichens) and (b) from the metal-enriched ambient atmosphere (particulates and dissolved ions) (Nieboer and Richardson 1981). The concentrations of trace elements in lichen thalli may be directly correlated with environmental levels of these elements (Loppi et al. 1999; Purvis et al. 2008; Shukla and Upreti 2007a). Therefore, lichen biomonitoring can be applied to assess the air quality of an area. However bioaccumulation is dependent on various factors, one of them being the contribution of the substratum on which lichen colonizes (Lodenius et al. 2010; Thormann 2006; Baker 1983; Markert et al. 2003; St. Clair et al. 2002).

Lichens are employed worldwide for air quality assessment either by mapping lichen diversity (LDV and IAP studies) or by carrying out transplant studies in 
polluted area and measuring bioaccumulation of contaminants within the thallus (Pfeiffer and Barclay-Estrup; 1992, Garty et al. 2003; Loppi and Frati 2006; Pinho et al. 2004; Shukla et al. 2010). Re- or neo-colonization of lichens has also been used to assess the air quality especially in metropolitan cities e.g. London, Madrid (Hawksworth and McManus 1989; Crespo et al. 2004).

Pyxine subcinerea Stirton is widely distributed in sub temperate regions of India. Earlier studies have been carried out to investigate the physiological response and concentration of polycyclic aromatic hydrocarbons in the species (Shukla and Upreti 2008; Shukla et al. 2011) but in order to propose it as an effective and reliable biomonitor for wider applicability, contribution of the substratum and the ambient atmosphere to the total metal concentration in the lichen, $P$. subcinerea is required to be investigated.

Thus, the aim of the present study was to discover, any significant correlation between the elemental composition of lichens and that of the bark or soil exists and hence to validate lichen, $P$. subcinerea Stirton as biomonitors of air pollution.

\section{Study area}

Haridwar city is an important holy pilgrimage and industrial hub of India, located in the southwestern part of Uttarakhand state (Lat. $29.96^{\circ} \mathrm{N}$, Long. $78.16^{\circ} \mathrm{E}$ ). The city is $249.7 \mathrm{~m}$ above sea level between the Shivalik Hills to the North and Northeast, and the Ganga River to the South. Temperatures range from 15 to $39.8^{\circ} \mathrm{C}$ in the summer and 6 to $16.6{ }^{\circ} \mathrm{C}$ in the winter. The Haridwar district has a population of about 2,95,213 (2001 India census). Haridwar is growing fast as a major industrial center since Uttarakhand became a new state. The State Infrastructure \& Industrial Development Corporation (SIDCUL) along with Bharat Heavy Electricals Limited (BHEL) controls large manufacturing plants, [Heavy Electrical Equipment Plant (HEEP) and Central Foundry Forge Plant (CFFP)]. These are located on the outskirts of the city. BHEL is the largest engineering and manufacturing enterprise in India and manufacturers, turbo generators, AC and DC motors, gas turbines, steel castings as well as steel forgings.

Tourism related to religious centre and industry is a major anthropogenic source of elevated metal levels in the ambient air of Haridwar city.

Air quality status in Haridwar city

The oxides of sulfur and nitrogen gases in Haridwar city are under prescribed limits set by the Central Pollution Control Board (CPCB), New Delhi. The ambient air concentration of $\mathrm{SO}_{2}$ recorded from Shivalik Nagar close to BHEL Township and SIDCUL area ranged between 8.64 and $12.30 \mu \mathrm{g} \mathrm{m}^{-3}$ and 13.33 and $20.12 \mu \mathrm{g} \mathrm{m}^{-3}$, while NOx gases were $13.12-19.40 \mu \mathrm{g} \mathrm{m}^{-3}$ and $18.33-24.40$ $\mu \mathrm{g} \mathrm{m}^{-3}$, respectively. However, the SPM and $\mathrm{PM}_{10}$ exceed limits set by $\mathrm{CPCB}$. The $\mathrm{PM}_{10}$ at the two sites in Haridwar city ranged from 98.47 to $141.28 \mu \mathrm{g} \mathrm{m}^{-3}$ and 160.80 to $175.78 \mu \mathrm{g} \mathrm{m}^{-3}$ and the SPM ranged from 357.12 to $413.33 \mu \mathrm{g} \mathrm{m}^{-3}$ and 497.12 to $599.36 \mu \mathrm{g} \mathrm{m}^{-3}$ (Chauhan et al. 2010).

\section{Materials and methods}

The area in and around Haridwar city was surveyed for lichens in July, 2009. Lichen samples were collected from 12 sampling sites in the city (Fig. 1). At each site, samples were taken from ten isolated Mango trees (Mangifera indica). Lichen specimens were collected from trees which fulfilled standard criteria of (a) trunk more than $35 \mathrm{~cm}$ in

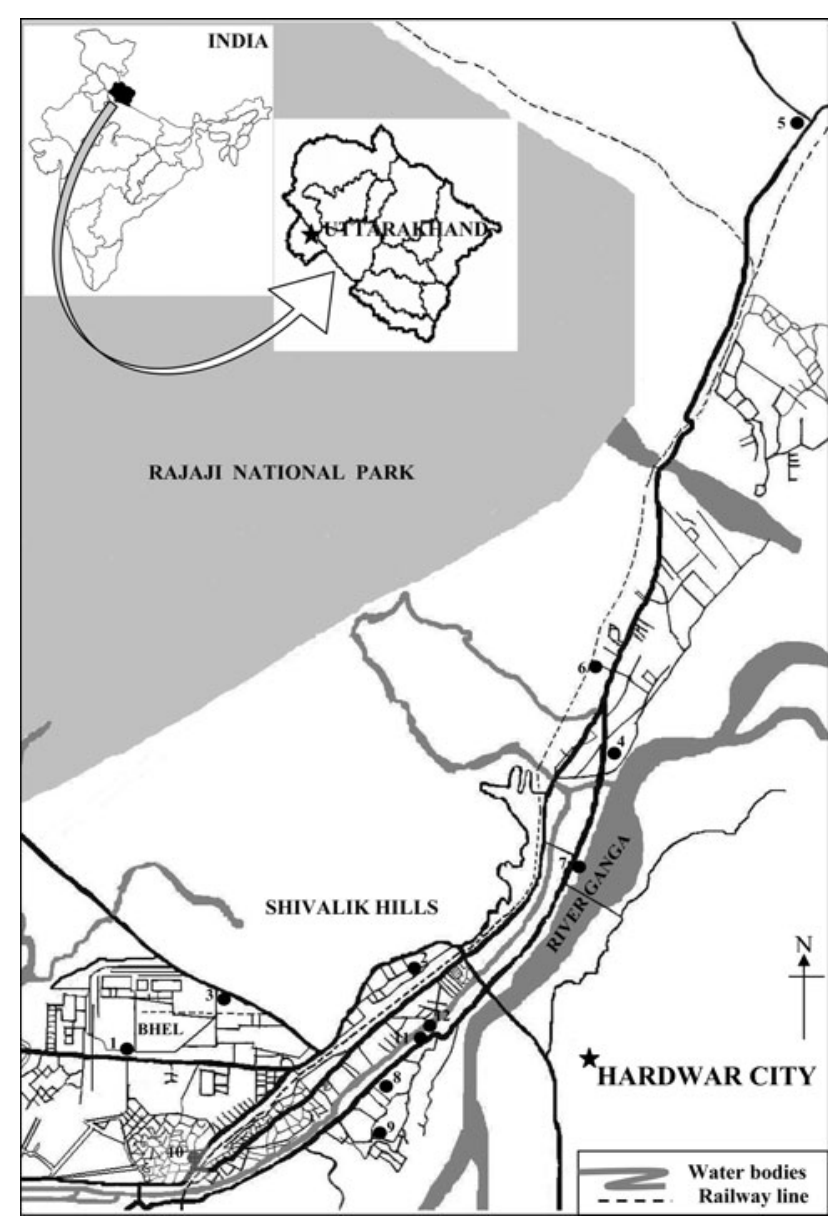

Fig. 1 Map showing different collection sites in and around Haridwar city, Uttarakhand, India. 1 BHEL (CFFP), 2 Roshnawala, SIDCUL, 3 BHEL, (HEEP), 4 Motichur, 5 Raiwala, 6 Motichur railway station, 7 Har ki Pauri, 8 Kankhal, Punjabi Khetra, 9 Kankhal, 10 Jwalapur, 11 Shankaracharya Chowk West, 12 Shankaracharya Chowk North 
diameter, (b) trunk inclination less than $75^{\circ}\left(15^{\circ}\right.$ deviation from vertical), (c) apparently healthy and (d) an available trunk height between 1.5 and $2 \mathrm{~m}$ above the ground. From each tree, 5-10 whole thalli of $P$. subcinerea were collected. In the laboratory, composite samples from each site were removed from the bark with sharp knife and sorted to remove extraneous material. The cleaned material was airdried. The substratum (bark) and a soil sample (collected from beneath the tree) from which lichen was also collected and processed so that their elemental composition could be determined.

\section{Metal analysis}

The dried lichen and bark samples (three replicates) were ground to a powder in mortar; $\approx 1.0 \mathrm{~g}$ each was digested in $5 \mathrm{ml}$ mixture of concentrated $\mathrm{HNO}_{3}$ and $\mathrm{HClO}_{4}$ (v/v 9:1) (beakers covered with watch glasses) for $1 \mathrm{~h}$ and then heated until close to dryness. Soil samples (weight $\approx 1.0 \mathrm{~g}$ each) were digested with conc. $\mathrm{HNO}_{3}(5 \mathrm{ml})$ for $8 \mathrm{~h}$. Residues were dissolved with $1 \% \mathrm{HNO}_{3}(2 \mathrm{ml})$ followed by filtration through Whatman Filter paper No. 42 and diluted to $25 \mathrm{ml}$ with $1 \% \mathrm{HNO}_{3}$. Analysis was done with Flame Atomic Absorption Spectrophotometer (Avanta- $\Sigma$, GBC, Australia). Stock standards were used from Merck India, traceable to NIST (National Institute of Standards Technology), to establish calibration curves that covered the region from 1,2 and $3 \mu \mathrm{gg}^{-1}$ levels. Sensitivity of atomic absorption was $0.1 \mu \mathrm{gg}^{-1}$ for all the metals detected.

\section{Statistical analysis}

The data obtained were subjected to one way analysis of variance (ANOVA) to evaluate the probable correlation pattern between the metal content from different sites using statistical program INDOSTAT (Hyderabad, India). Linear regressions and Pearsons correlations were obtained using MS EXCEL.

\section{Results and discussion}

Multi elemental contents in the lichen $P$. subcinerea, Mango bark and soil were compared, which revealed that total metal content in lichen, bark and soil ranged from 1,573 to $18,793,256$ to 590 and 684 to $801 \mu \mathrm{g} \mathrm{g}^{-1}$, respectively (Table 1). The possible source of elements may be deduced from the pattern of elements in the sampled lichen (Table 2). Concentration of $\mathrm{Pb}$ and $\mathrm{Ni}$ was highest at the city centre highly influenced by the traffic activity followed by industrial sites. Pirintsos et al. (2006) concluded that enhanced levels of $\mathrm{Cu}$ and $\mathrm{Zn}, \mathrm{Fe}$ and $\mathrm{Zn}$,
$\mathrm{Cd}$ and $\mathrm{Fe}, \mathrm{Cd}$ and $\mathrm{Zn}$, and $\mathrm{Pb}$ and $\mathrm{Ni}$ indicated motor vehicles as the possible origin and the same was found in the present study (Table 3, significant at $P<0.05$ ). Vehicular activity is reported to be the main source of atmospheric $\mathrm{Cr}, \mathrm{Cu}$ and $\mathrm{Pb}$ (Loppi et al. 1998; Tuba and Csintalan 1993).

Cadmium is a constituent of lubricating motor oil, tyres and galvanized parts of vehicles, for example, concentrations range from 0.07 to $0.10 \mathrm{ppm}$ in diesel oils and from 0.20 to $0.026 \mathrm{ppm}$ in lubricating oils, while in automobile tyres levels range from 20 to 90 ppm (Kannan 1997). In the present study, the cadmium concentration was quite high in the lichen samples $\left(4.2-51.45 \mu \mathrm{g} \mathrm{g}^{-1}\right)$ compared with its concentration in bark $\left(0.45-2.97 \mu \mathrm{g} \mathrm{g}^{-1}\right)$ or soil $(0.3-$ $\left.2.19 \mu \mathrm{g} \mathrm{g}^{-1}\right)$. This indicates an atmospheric origin for this metal. Competition between the metals to bind with sites holding the cations affects the uptake of metal (Nieboer and Richardson 1981). Hardiman and Jacoby (1984) observed that absorption of $\mathrm{Cd}$ by plant root was reduced in the presence of other cations of increasing valency or ionic radii.

Zinc is a component of automobile tyres and brake pads while nickel is found in car metal plating in welds and in tyres (Ward 1989; Sadiq et al. 1989). The current investigation (Table 3 ) suggests that there is a significant positive correlation between $\mathrm{Cu}$ and $\mathrm{Zn}(r=0.5841)$ in lichens of Haridwar city, which indicates an anthropogenic origin.

The chromium concentration in non-polluted environments is reported to be quite low (Chettri et al. 1997). Cr uptake occurs as hexavalent chromate $\left(\mathrm{CrO}_{4}{ }^{2-}\right)$ which is rapidly reduced to $\mathrm{Cr}^{3+}$ in soil. The trivalent form of $\mathrm{Cr}$ is absorbed minimally by root and its translocation from root to other parts is low (Streit and Stumm 1993). In the present study, $\mathrm{Cr}$ concentrations were quite low in bark $\left(3.4 \pm 0.33 \mu \mathrm{g} \mathrm{g}^{-1}\right)$ compared with soil $(22.1 \pm 1.68$ $\left.\mu \mathrm{g} \mathrm{g}^{-1}\right)$ and lichens $\left(42.7 \pm 2.62 \mu \mathrm{g} \mathrm{g}^{-1}\right)$, which reflects the fact that lichens and soil act as sinks for the pollutants. The $\mathrm{Pb}$ content ranged from 17.3 to $158 \mu \mathrm{g} \mathrm{g}^{-1}$ which is quite low in comparison to $\mathrm{Pb}$ levels in other cities of Uttarakhand [Dehradun city: 66.6-12,433 $\mu \mathrm{g} \mathrm{g}^{-1}$ (Rani et al. 2011) and Pauri city: 231.9-425.9 $\mu \mathrm{g} \mathrm{g}^{-1}$ (Shukla and Upreti 2007b)]. This may be due to two factors: (i) the introduction of unleaded petrol and (ii) Haridwar is the starting point of the 'Holy voyage' and authorities encourage diesel-powered over petroleum-driven vehicles. The present observations are consistent with the findings of Ormrod (1984) and suggest that $\mathrm{Pb}, \mathrm{Zn}, \mathrm{Cd}$, and $\mathrm{Cu}$ levels are linked with automobile traffic emissions.

Functional relationships were tested by applying linear regression. Scatter plots (Figs. 2, 3, 4) showed that there was no significant linear correlation between most of the metal in lichen and soil, affirming the atmospheric origin of these metals. The soil versus bark metal concentrations 





Table 2 Mineral element concentrations in thalli of Pyxine subcinerea collected from various sites of Haridwar city

\begin{tabular}{lclccccc}
\hline & $\mathrm{Cd}$ & $\mathrm{Cr}$ & $\mathrm{Cu}$ & $\mathrm{Fe}$ & $\mathrm{Ni}$ & $\mathrm{Pb}$ & $\mathrm{Zn}$ \\
\hline 1 & $6.9 \pm 2.77$ & $39.9 \pm 6.05$ & $20.4 \pm 3.4$ & $4,500 \pm 224$ & $25.50 \pm 4.63$ & $42.3 \pm 2.84$ & $224 \pm 19.0$ \\
2 & $32.1 \pm 5.05$ & $32.1 \pm 3.08$ & $42.0 \pm 2.16$ & $7,410 \pm 605$ & $148.20 \pm 4.39$ & $102.75 \pm 5.19$ & $605 \pm 19.8$ \\
3 & $4.2 \pm 0.69$ & $18.0 \pm 2.1$ & $19.65 \pm 1.03$ & $4,005 \pm 143$ & $187.80 \pm 9.1$ & $36.45 \pm 3.23$ & $143 \pm 14.2$ \\
4 & $19.0 \pm 2.98$ & $16.4 \pm 4.2$ & $30.15 \pm 2.79$ & $16,185 \pm 608$ & $448.65 \pm 51.8$ & $98.25 \pm 12.2$ & $608 \pm 15.7$ \\
5 & $21.45 \pm 1.3$ & $94.4 \pm 3.8$ & $32.40 \pm 2.51$ & $3,105 \pm 158$ & $139.65 \pm 41.9$ & $21.15 \pm 3.99$ & $158 \pm 8.28$ \\
6 & $31.20 \pm 1.7$ & $65.9 \pm 11.43$ & $114.15 \pm 6.26$ & $5,265 \pm 733$ & $719.25 \pm 28.6$ & $157.8 \pm 10.61$ & $733 \pm 4.54$ \\
7 & $30.45 \pm 2.6$ & $40.4 \pm 2.04$ & $43.95 \pm 3.44$ & $8,805 \pm 260$ & $284 \pm 4.5$ & $36.90 \pm 1.32$ & $260 \pm 19.13$ \\
8 & $10.35 \pm 0.6$ & $22.9 \pm 4.18$ & $36.15 \pm 2.69$ & $4,365 \pm 162$ & $420.6 \pm 17.5$ & $67.35 \pm 1.68$ & $162 \pm 19.13$ \\
9 & $14.10 \pm 1.4$ & $44.9 \pm 5.75$ & $36.30 \pm 2.74$ & $3,045 \pm 663$ & $13.50 \pm 1.64$ & $17.25 \pm 2.36$ & $663 \pm 31.9$ \\
10 & $6.0 \pm 0.707$ & $17.6 \pm 2.99$ & $23.85 \pm 4.26$ & $795 \pm 494$ & $189.45 \pm 11.4$ & $47.55 \pm 3.78$ & $494 \pm 19.44$ \\
11 & $51.45 \pm 2.4$ & $74.1 \pm 4.41$ & $113.4 \pm 11.55$ & $17,280 \pm 1178$ & $52.35 \pm 2.41$ & $43.8 \pm 1.98$ & $1178 \pm 138$ \\
12 & $6.15 \pm 0.75$ & $45.8 \pm 6.4$ & $144.1 \pm 4.90$ & $870 \pm 502$ & $303.3 \pm 13.77$ & $41.4 \pm 4.91$ & $502 \pm 11.8$ \\
$F$ ratio & 78.01 & 87.9 & 166.59 & 220.12 & 167.85 & 119.88 & 0.00 \\
$F$ prob. & 0.00 & 0.00 & 0.00 & 0.00 & 0.00 & 104.4 \\
\hline Concen & & & & 0.00 \\
\hline
\end{tabular}

Concentrations are given as $\mu \mathrm{g} \mathrm{g}^{-1}$ dry wt. (values expressed as mean \pm standard error) and $F$ values along with $F$ probability obtained by one way ANOVA analysis

1 BHEL (CFFP) (industrial), 2 Roshnawala, SIDCUL (industrial), 3 BHEL, (HEEP) (industrial), 4 Motichur (periurban), 5 Raiwala (periurban), 6 Motichur railway station (periurban), 7 Har ki Pauri, (city center) 8 Kankhal (urban), Punjabi Khetra (urban), 9 Kankhal (urban), 10 Jwalapur (urban), 11 Shankaracharya Chowk West (urban), 12 Shankaracharya Chowk North (urban)

Table 3 Values of correlation coefficient between the elements analyzed in lichen, $P$. subcinerea

\begin{tabular}{|c|c|c|c|c|c|c|}
\hline & $\mathrm{Cu}$ & $\mathrm{Pb}$ & $\mathrm{Cd}$ & $\mathrm{Ni}$ & $\mathrm{Fe}$ & $\mathrm{Zn}$ \\
\hline $\mathrm{Cr}$ & 0.4531 & -0.0962 & 0.5422 & -0.0963 & 0.0659 & 0.2732 \\
\hline $\mathrm{Cu}$ & & 0.2764 & 0.4004 & 0.3346 & 0.1120 & $0.5841 *$ \\
\hline $\mathrm{Pb}$ & & & 0.3025 & $0.7868 * *$ & 0.2470 & 0.3124 \\
\hline $\mathrm{Cd}$ & & & & 0.0494 & $0.7148 * *$ & $0.6899 * *$ \\
\hline $\mathrm{Ni}$ & & & & & 0.0555 & 0.0038 \\
\hline $\mathrm{Fe}$ & & & & & & $0.5628 *$ \\
\hline
\end{tabular}

$* P<0.05, * * P<0.01$

showed a non-significant correlation. Pearsons correlation was then applied to establish the strength of the linear relationship. The Pearsons correlation (Table 4) further substantiated the atmospheric origin of the metals present at higher concentrations in the lichen samples. The Pearson correlation also showed a weak negative correlation of $\mathrm{Pb}$ content $(r=-0.2245)$ and $\mathrm{Ni}(r=-0.0480)$ in lichen and soil, affirming the anthropogenic origin. The metals like $\mathrm{Cu}, \mathrm{Cr}$ and $\mathrm{Zn}$ showed positive correlation between lichen and bark content $(\mathrm{Cu}: r=0.6932:: \mathrm{Cr}: r=0.8642:: \mathrm{Zn}$ : 0.5434 ), which suggests that bioaccumulation of these metals in lichens is both from direct atmospheric deposition and also through the bark of the trees when growing in contaminated soil.
The morphology and anatomy of lichen play an important role in the accumulation of metals (Goyal and Seaward 1982). Among the different foliose lichens, P.subcinerea accumulates higher ranges of metals than Ramalina lacera (With.) J.R. Laund., Parmelia sulcata, Evernia prunastri, which are utilized for biomonitoring of inorganic pollutants in other parts of the world (Garty et al. 2003; Loppi et al. 1998, 1999; Lodenius et al. 2010). Result also indicates that Phaeophyscia hispidula, a closely related Physciaceae member, quite similar in morphology accumulates higher concentration of metals especially iron in comparison to P. subcinerea (Shukla and Upreti 2007b; Rani et al. 2011). The probable reason of higher metal content may be due to presence of dense tuft of rhizinae on the lower side of thallus which act as metal reservoir (Goyal and Seaward 1982).

\section{Conclusion}

The present study suggests that the elevated metal content of $P$. subcinerea in Haridwar city, India, is mainly due to adsorption/absorption from direct atmospheric input of anthropogenic origin. The statistical treatment of the lichen biomonitoring data helps to elucidate the sources of inorganic pollutants (substratum and/or atmosphere) and helps 

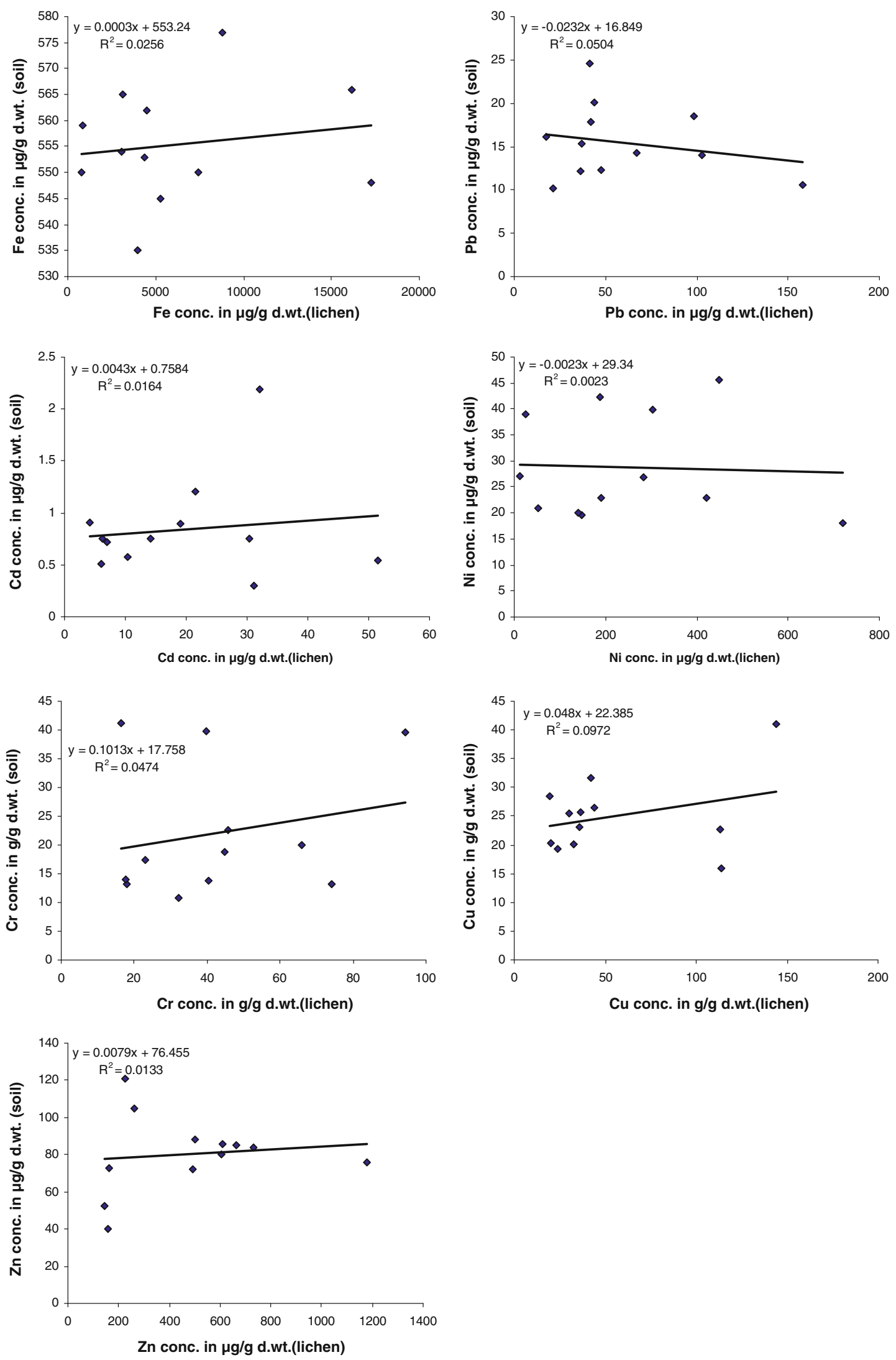

Fig. 2 Scatter plot showing the linear regression between the individual metal concentration (in $\mu \mathrm{g} / \mathrm{g}$ ) in lichen and soil at 12 sampling sites in Haridwar city 

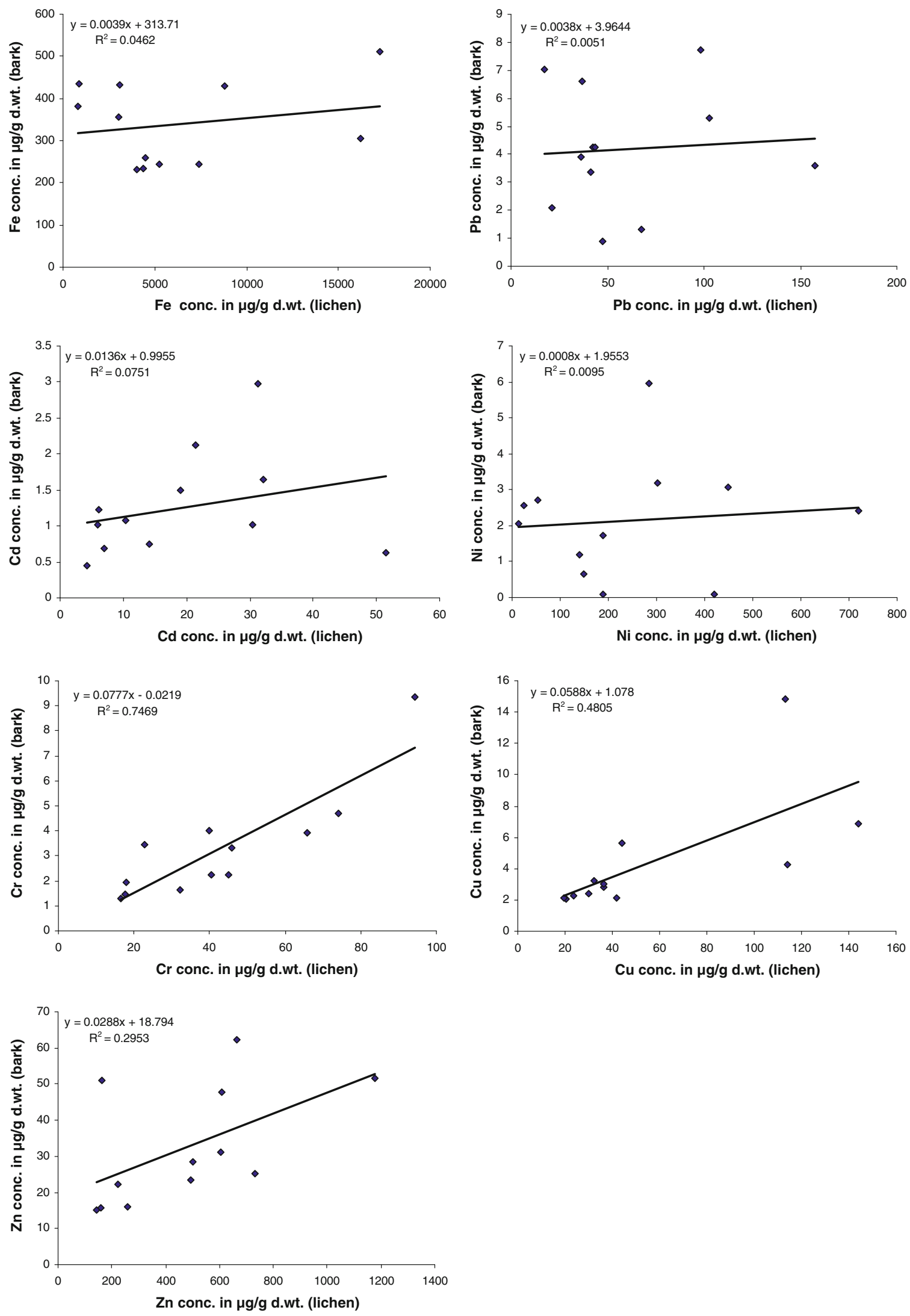

Fig. 3 Scatter plot showing the linear regression of individual metal concentration (in $\mu \mathrm{g} / \mathrm{g}$ ) in lichen and bark samples at 12 sampling sites in Haridwar city 

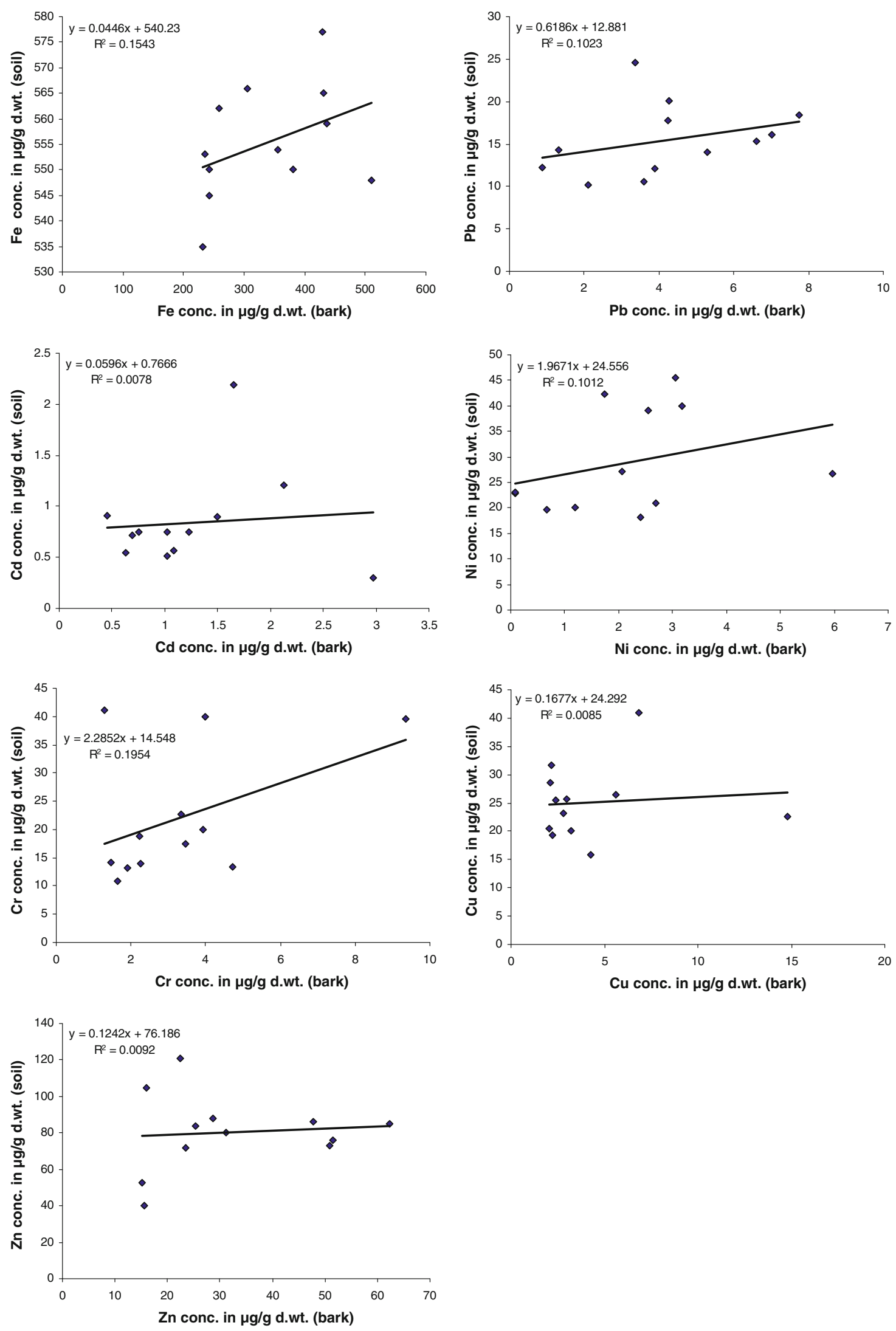

Fig. 4 Scatter plot showing the linear regression of individual metal concentration (in $\mu \mathrm{g} / \mathrm{g}$ ) in soil and bark samples at 12 sampling sites in Haridwar city 
Table 4 Pearsons correlation between individual elemental concentration in lichen with bark and soil and between bark and soil

\begin{tabular}{llcl}
\hline & Lichen versus bark & Lichen versus soil & Bark versus soil \\
\hline $\mathrm{Cr}$ & $0.8642^{* *}$ & 0.2178 & 0.4419 \\
$\mathrm{Cu}$ & $0.6932^{* *}$ & 0.3118 & 0.0923 \\
$\mathrm{~Pb}$ & 0.0712 & -0.2245 & 0.3198 \\
$\mathrm{Cd}$ & 0.2741 & 0.1282 & 0.0885 \\
$\mathrm{Ni}$ & 0.0977 & -0.0480 & 0.3181 \\
$\mathrm{Fe}$ & 0.2151 & 0.1601 & 0.3927 \\
$\mathrm{Zn}$ & $0.5434^{* *}$ & 0.1154 & 0.0960 \\
\hline
\end{tabular}

$* P<0.05, * * P<0.01$

to distinguish between the contribution of the substratum and atmospheric inputs of metals.

Thus the present study establishes value of the lichen $P$. subcinerea Stirton, as a biomonitor for inorganic pollutants when assessing air quality of urban/industrial area in the Indian subcontinent.

Acknowledgments Authors (M.Y. and V.S.) are thankful to the Vice Chancellor, Babasaheb Bhimrao Ambedkar (Central) University, Lucknow for providing Laboratory facilities. V.S. wishes to thanks Scientific and Engineering Research Council Division, Department of Science and Technology, New Delhi (SR/FT/LS-028/ 2008) for the financial support. Authors wish to thank Dr. Sudhir Shukla for statistical analysis of the data and Ms Anu Rastogi for valuable help.

\section{References}

Baker DA (1983) Uptake of cations and their transport within the plants. In: Robb DA, Pierpoint WS (eds) Metals and micronutrients: uptake and utilization by plants. Academic Press, London, pp 3-19

Bjerke JW (2011) Winter climate change: ice encapsulation at mild subfreezing temperatures kills freeze-tolerant lichens. Environ Exp Bot 72:404-408

Chauhan A, Pawar M, Kumar R, Joshi PC (2010) Ambient air quality status in Uttarakhand (India): a case study of Haridwar and Dehradun using air quality index. J Am Sci 6(9):565-574

Chettri MK, Sawidis T, Karataglis S (1997) Lichens as a tool for biogeochemical prospecting. Ecotoxicol Environ Saf 38:322-335

Crespo A, Divakar PK, Argüello A, Gasca C, Hawksworth DL (2004) Molecular studies on Punctelia species of the Iberian Peninsula, with an emphasis on specimens newly colonizing Madrid. The Lichenologist 36:299-308

Garty J, Tomer S, Levin T, Lehra H (2003) Lichens as biomonitors around a coal-fired power station in Israel. Environ Res 91: $186-198$

Goyal R, Seaward MRD (1982) Metal uptake in terricolous lichens. II. Translocation in the thallus of Peltigera canina. New Phytol 90:85-98

Green T, Sancho L, Türk R, Seppelt R, Hogg I (2011) High diversity of lichens at $84^{\circ} \mathrm{S}$, Queen Maud Mountains, suggests preglacial survival of species in the Ross Sea region, Antarctica. Polar Biol $34: 1211-1220$
Hardiman RT, Jacoby B (1984) Absorption and translocation of Cd in bush beans (Phaseolus vulgaris). Physiol Plant 61:670-674

Hawksworth DL, McManus PM (1989) Lichen recolonization in London under conditions of rapidly falling sulphur dioxide, and the concept of zone skipping. J Linn Soc Bot 100:99-109

Kannan K (1997) Fundamentals of Environmental Pollution. S. Chand and Co. Ltd, New Delhi

Lodenius M, Kiiskinen J, Tulisalo E (2010) Metal levels in an epiphytic lichen as indicators of air quality in a suburb of Helsinki, Finland. Boreal Environ Res 15:446-452

Loppi S, Frati L (2006) Lichen diversity and lichen transplants as monitors of air pollution in a rural area of central Italy. Environ Monit Assess 114:361-375

Loppi S, Pacioni G, Olivieri N, Di Giacomo F (1998) Accumulation of trace metals in the lichen Evernia prunasteri transplanted at biomonitoring sites in Central Italy. Bryologist 101(3):451-454

Loppi S, Pirintsos SA, Dominics V (1999) Soil contribution to the elemental composition of epiphytic lichens (Tuscany, Central Italy). Environ Monit Assess 58:121-131

Markert BA, Breure AM, Zechmeister HG (2003) Definitions, strategies and principles for bioindication/biomonitoring of the environment. In: Markert BA, Breure AM, Zechmeister HG (eds) Bioindicators and biomonitors. Elsevier, Oxford, pp 3-39

McCune B (2000) Lichen communities as indicators of forest health. The Bryologist 103:353-356

Nieboer E, Richardson DHS (1981) Lichens as monitors of atmospheric deposition. In: Eisenreich SJ (ed) Atmospheric inputs of pollutants to natural waters. An Arbor Science Publishing, Michigan, pp 339-388

Nimis PL, Scheidegger C, Wolseley P (2002) Monitoring with lichens-monitoring lichens. Kluwer Academics, Dordrecht

Ormrod DP (1984) Impact of trace element pollution on plant species. In: Treshow M (ed) Air pollution and plant life. Wiley \& Sons, New York, pp 291-319

Paoli L, Loppi S (2008) A biological method to monitor early effect of the air pollution. Environ Pollut 155:383-388

Pfeiffer HN, Barclay-Estrup P (1992) The use of a single lichen species, Hypogymnia physodes as an indicator of air quality in Northwestern Ontario. Bryologist 95:38-41

Pinho P, Augusto S, Branquinho C, Bio A, Pereira MJ, Soares A, Catarino F (2004) Mapping lichen diversity as a first step for air quality assessment. J Atm Chem 49:377-389

Pirintsos SA, Matsi T, Vokou D, Gaggi C, Loppi S (2006) Vertical distribution patterns of trace elements in an urban environment as reflected by their accumulation in lichen transplant. J Atmos Chem 54:121-131

Purvis OW, Dubbin W, Chimonides PDJ, Jones GC, Read H (2008) The multielement content of the lichen Parmelia sulcata, soil, and oak bark in relation to acidification and climate. Sci Total Environ 390:558-568

Rani M, Shukla V, Upreti DK, Rajwar GS (2011) Periodical monitoring with lichen, Phaeophyscia hispidula (Ach.) Moberg in Dehradun city, Uttarakhand, India. Environmentalist 31:376381

Sadiq M, Alam I, El-Mubarek A, Al-Mohdar HM (1989) Preliminary evaluation of metal pollution from wear of auto tires. Bull Environ Contam Toxicol 42:743-748

Shukla V, Upreti DK (2007a) Physiological response of the lichen Phaeophyscia hispidula (Ach.) Essl. to the urban environment of Pauri and Srinagar (Garhwal), Himalayas. Environ Pollut 150: 295-299

Shukla V, Upreti DK (2007b) Heavy metal accumulation in Phaeophyscia hispidula en route to Badrinath, Uttaranchal, India. Environ Monit Assess 131:365-369 
Shukla V, Upreti DK (2008) Effect of metallic pollutants on the physiology of lichen, Pyxine subcinerea Stirton in Garhwal Himalayas. Environ Monit Assess 141:237-243

Shukla V, Upreti DK, Patel DK, Tripathi R (2010) Accumulation of polycyclic aromatic hydrocarbons in some lichens of Garhwal Himalayas, India. Int J Environ Waste Manag 5(1/2):104-113

Shukla V, Patel DK, Upreti DK, Yunus M (2011) Lichens to distinguish urban from industrial PAHs. Environ Chem Lett. doi: 10.1007/s10311-011-0336-0

St. Clair BS, St. Clair LL, Weber JD, Mangelson FN, Eggett LD (2002) Element accumulation patterns in foliose and fruticose lichens from rock and bark substrates in Arizona. The Bryologist 105:415-421

Streit B, Stumm W (1993) Chemical properties of metals and the process of bioaccumulation in terrestrial plants. In: Markert B (ed) Plants as Biomonitors. VCH, Weinheim, pp 31-62
Thormann MN (2006) Lichens as indicators of forest health in Canada. The Forestry Chronicle 82(3):335-343

Tuba Z, Csintalan Z (1993) Bioindication of road motor traffic caused heavy metal pollution by lichen transplants. In: Markert B (ed) Plants as biomonitors Indicators for heavy metal in the terrestrial environment. VCH, Weinheim, pp 329-341

Ward NI (1989) Multielement contamination of British motorway environments. In: Vernet JP (ed) Heavy metals in the environment. International conference, vol II, Geneva. CEP Consultant, Edinburgh, pp 279-282

Wolterbeek HTh, Garty J, Reis MA, Freitas MC (2003) Biomonitors in use: lichens and metal air pollution. In: Breure AM, Zechmeister HG, Markert BA (eds) Bioindicators and biomonitors. Elsevier, Oxford, pp 377-419 